\title{
In the Absence of the Low Density Lipoprotein Receptor, Human Apolipoprotein C1 Overexpression in Transgenic Mice Inhibits the Hepatic Uptake of Very Low Density Lipoproteins via a Receptor-associated Protein-sensitive Pathway
}

\author{
Miek C. Jong, ${ }^{\star}$ Vivian E.H. DahImans, ${ }^{*}$ Patrick J.J. van Gorp, ${ }^{\ddagger}$ Ko Willems van Dijk, ${ }^{\ddagger}$ Marco L. Breuer, ${ }^{\S}$ Marten H. Hofker, ${ }^{\ddagger}$ \\ and Louis M. Havekes* \\ *TNO Prevention and Health, TNO-PG Gaubius Laboratory, 2301CE Leiden, The Netherlands; and ${ }^{\ddagger}$ Department of Human Genetics \\ and ${ }^{\S}$ Department of Molecular Carcinogenesis, Leiden University 2300AR, Leiden, The Netherlands
}

\begin{abstract}
To study the role of apoC1 in lipoprotein metabolism, we have generated transgenic mice expressing the human APOC1 gene. On a sucrose-rich diet, male transgenic mice with high APOC1 expression in the liver showed elevated levels of serum cholesterol and triglyceride compared with control mice $(5.7 \pm 0.7$ and $3.3 \pm 2.1$ vs. $2.7 \pm 0.1$ and $0.4 \pm 0.1$ $\mathrm{mmol} / \mathrm{liter}$, respectively). These elevated levels were mainly confined to the VLDL fraction. Female APOC1 transgenic mice showed less pronounced elevated serum lipid levels. In vivo VLDL turnover studies revealed that, in hyperlipidemic APOC1 transgenic mice, VLDL particles are cleared less efficiently from the circulation as compared with control mice. No differences were observed in the hepatic production and extrahepatic lipolysis of VLDL-triglyceride. Also, VLDL isolated from control and APOC1 transgenic mice were found to be equally good substrates for bovine lipoprotein lipase in vitro. These data indicate that the hyperlipidemia in APOC1 transgenic mice results primarily from impaired hepatic VLDL particle clearance, rather than a defect in the hydrolysis of VLDL-triglyceride.

To investigate which hepatic receptor is involved in the apoC1-mediated inhibition of VLDL clearance, APOC1 transgenic mice were bred with an LDL receptor-deficient (LDLR ${ }^{-1-}$ ) background. In addition, control, $\mathrm{LDLR}^{-1-}$, and $\mathrm{LDLR}^{-1-} /$ APOC1 mice were transfected with adenovirus carrying the gene for the receptor-associated protein (AdRAP). Both serum cholesterol and triglyceride levels were strongly elevated in $\mathrm{LDLR}^{-1-} / \mathrm{APOC} 1$ mice compared with LDLR $^{-1-}$ mice $(52 \pm 19$ and $36 \pm 19$ vs. $8.4 \pm 0.9$ and $0.5 \pm 0.2$ $\mathrm{mmol} /$ liter, respectively), indicating that apoC1 inhibits the alternative VLDL clearance pathway via the remnant receptor. Transfection of $\mathrm{LDLR}^{-l-}$ mice with Ad-RAP strongly increased serum cholesterol and triglyceride levels, but to a lesser extent than those found in $\mathrm{LDLR}^{-1-} / \mathrm{APOC} 1$ mice $(39 \pm 8$ and $17 \pm 8$ vs. $52 \pm 19$ and $36 \pm 19 \mathrm{mmol} / \mathrm{liter}$, respectively). However, in $\mathrm{LDLR}^{-1-} / \mathrm{APOC} 1$ mice the transfection with Ad-RAP did not further increase serum cholesterol
\end{abstract}

Address correspondence to Louis M. Havekes, TNO-PG, Gaubius Laboratory, P.O. Box 2215, 2301 CE Leiden, The Netherlands. Phone: 3171-5181449; FAX: 31-71-5181904; E-mail: 1m.havekes@pg.tno.nl

Received for publication 5 April 1996 and accepted in revised form 15 August 1996.

J. Clin. Invest.

(C) The American Society for Clinical Investigation, Inc.

0021-9738/96/11/2259/09 \$2.00

Volume 98, Number 10, November 1996, 2259-2267 and triglyceride levels (52 \pm 19 and $36 \pm 19$ vs. $60 \pm 10$ and $38 \pm 7 \mathrm{mmol} / \mathrm{liter}$, respectively). From these studies we conclude that, in the absence of the LDLR, apoC1 inhibits the hepatic uptake of VLDL via a RAP-sensitive pathway. ( $J$. Clin. Invest. 1996. 98:2259-2267.) Key words: apolipoprotein C1 • low density lipoprotein receptor • low density lipoprotein receptor-related protein $\bullet$ hyperlipoproteinemia $\bullet$ lipoprotein lipase

\section{Introduction}

Human apoC1 is a $6.6-\mathrm{kD}$ protein that is present on chylomicrons, VLDL, and HDL (1). It has been suggested that apoC1 inhibits the lipoprotein lipase (LPL) ${ }^{1}$-mediated hydro-lysis of VLDL-triglyceride $(2,3)$. In vitro studies showed that the addition of purified human apoC1 to chylomicrons (4) and triglyceride emulsions (5) inhibits their uptake by perfused rat livers. Studies by Sehayek and Eisenberg (6) revealed that apoC1 impairs the apoE-mediated binding of VLDL to the LDL receptor (LDLR), whereas Weisgraber et al. (7) showed that the addition of apoC1 to apoE-enriched $\beta$-VLDL inhibits its binding to the LDLR-related protein (LRP). Thus, in vitro studies indicate that apoC1 interferes with both the peripheral lipolysis of VLDL and the hepatic uptake of VLDL remnants. Although the underlying mechanism by which apoC1 inhibits the apoE-mediated binding to hepatic receptors in vitro is still unclear, it is assumed to be due to either a shift in the conformation of apoE $(4,6)$ or to the displacement of apoE from the VLDL particle $(7,8)$.

The observation that transgenic mice overexpressing the human APOC1 gene showed two- to threefold higher plasma triglyceride levels than control mice (9) suggests that the direct inhibiting effect of apoC1 on either VLDL-triglyceride lipolysis or the binding of VLDL to the LDLR and LRP holds true for the in vivo situation as well. However, such a role for apoC1 could not be concluded from the results we obtained with Apoc1-deficient mice (10). These mice have normal serum lipid levels on a regular chow diet; whereas, suprisingly, on a severe hypercholesterolemic diet they display mildly ele-

1. Abbreviations used in this paper: $\alpha_{2}-\mathrm{M}, \alpha_{2}$-macroglobulin; Ad- $\beta-G a l$, adenoviral vectors expressing $\beta$-galactosidase; Ad-RAP, adenovirus carrying the gene for RAP; FCR, fractional catabolic rate; FPLC, fast protein liquid chromatography; GAPDH, glyceraldehyde-3-phosphate dehydrogenase; HFC, high fat/high cholesterol diet; LDLR, low density lipoprotein receptor; LFC, low fat/low cholesterol diet; LPL, lipoprotein lipase; LR, lipolytic rate; LRP, LDL receptor related protein; PFU, plaque-forming units; RAP, receptor associated protein; SR, secretion rate; SRM-A, standard rat mouse diet (chow); $\mathrm{V}_{\max }$, maximal enzyme activities. 
vated levels of serum cholesterol due to a decreased binding of apoC1-deficient VLDL to the LDLR.

In the present paper, we describe in vivo VLDL turnover studies with transgenic mice expressing human APOC1 at different levels. These studies showed that apoC1 indeed inhibits the hepatic clearance of VLDL, but does not affect the VLDLtriglyceride hydrolysis. By a combination of breeding these APOC1 transgenic mice on homozygosity for LDLR deficiency (APOC1/LDLR ${ }^{-1-}$ ) and transfection with adenovirus containing the receptor-associated protein-gene (Ad-RAP), we were able to show that at least in the absence of the LDLR, apoC1 inhibits the hepatic uptake of VLDL via a RAP-sensitive pathway, most probably LRP.

\section{Methods}

DNA construct. The APOC1 construct was generated by the excision of an 18-kb EcoRI fragment from a cosmid carrying the APOE*4/ APOC1/APOC1' gene region. The fragment contained a 5-kb region upstream from APOC1 and an 8-kb region downstream from APOC1, including the hepatic control region element and part of APOC1 pseudo gene.

Generation and analysis of transgenic mice. Transgenic mice, expressing human APOC1 were generated according to Hogan et al. (11). Transgenic offspring were identified by polymerase chain reaction analysis and Southern blot analysis on genomic tail-derived DNA (12). Two founders were characterized according to which low expressor and high expressor were bred with C57BL/6J mice. APOC1 transgenic mice of the $\mathrm{F} 3$ generation have been used in all the experiments. Female high expressor APOC1 transgenic mice were crossbred with male LDLR-deficient mice, purchased from The Jackson Laboratories (Bar Harbor, ME). All mice in this study were housed under standard conditions with free access to water and food. Nontransgenic litter mates were used as the control group. All experiments were performed at $1300 \mathrm{~h}$ with food withdrawn at $0900 \mathrm{~h}$.

Preparation and analysis of RNA. Total RNA was isolated from the livers of transgenic mice using the RNAZOL procedure (Cinna/ Biotecx, Friendswood, TX). Human APOC1 and mouse Apoc1 and Apoe transcripts were detected by Northern blotting after electrophoresis of RNA samples (7.5 $\mu \mathrm{g}$ per lane) on a denaturing agarose gel $(1 \% \mathrm{wt} / \mathrm{vol})$ containing $7.5 \%$ formaldehyde and transferred to a nylon membrane (Hybond N; Amersham Corp., Arlington Heights, IL) according to the manufacturer's recommendations. Blots were subsequently hybridized with a ${ }^{32} \mathrm{P}$-labeled probe of human APOC1 cDNA (13), mouse Apoc1 cDNA (14), mouse Apoe cDNA (15), and a rat glyceraldehyde-3-phosphate dehydrogenase (GAPDH) cDNA (16) in a solution containing $50 \%$ formamide. The intensity of the hybridization signal was quantified with a Phosphor Imager (Molecular Dynamics, Inc., Sunnyvale, CA) and the amounts of human APOC1 mRNA, mouse Apoc1 mRNA, and mouse Apoe mRNA were related to the level of GAPDH mRNA.

Diet study. Mice were fed a standard rat mouse (SRM-A) diet (chow) immediately after weaning at $4 \mathrm{wk}$ of age. After $7 \mathrm{wk}$ of age, two different semisynthetic diets, composed essentially according to Nishina et al. (17) (purchased from Hope Farms, Woerden, The Netherlands), were administered subsequently to groups of each strain (at least seven mice per group). First, mice were fed a low fat/ low cholesterol (LFC) diet containing $50.5 \%$ sucrose, $12.2 \%$ corn starch, $5 \%$ corn oil, and $5 \%$ cellulose by weight (18) for $3 \mathrm{wk}$. The same mice were fed a high fat/high cholesterol (HFC) diet containing $15 \%$ cocoa butter, $0.25 \%$ cholesterol, and sucrose by weight for another 3 wk (19). After each dietary treatment, $100 \mu l$ of whole blood was obtained from each mouse via tail bleeding.

Analysis of serum lipids and lipoproteins. Levels of total serum cholesterol and serum triglyceride (without measuring free glycerol) were determined using commercially available enzymatic kits
(236691; Boehringer Mannheim GmbH, Mannheim, Germany, and 337-B; Sigma GPO-Trinder kit; Sigma Chemical Co., St. Louis, MO), respectively. Triglyceride, free cholesterol, and phospholipid in the individual lipoprotein fractions were measured with enzymatic assay kits (701904 and 310328; Boehringer-Mannheim $\mathrm{GmbH}$ ) and an analytical kit (B) from Wako Chemicals GmbH (Neuss, Germany), respectively. Cholesterol esters are total cholesterol minus free cholesterol. Serum FFA were determined with the $\mathrm{NeFa}-\mathrm{C}$ kit from WAKO Chemicals $\mathrm{GmbH}$ according to the manufacturer's recommendation.

Pooled serum $(200 \mu \mathrm{l})$ collected from at least seven fasted mice per group was subjected to fast protein liquid chromatography (FPLC) gel filtration on two (connected in series) 25-ml Superose 6 preparation-grade columns (Pharmacia Diagnostics AB, Uppsala, Sweden), and eluted at a constant flow rate of $0.5 \mathrm{ml} / \mathrm{min}$ with PBS, $\mathrm{pH}$ 7.4. Fractions of $0.5 \mathrm{ml}$ were collected and assayed for cholesterol and triglyceride as described above.

The individual lipoprotein fractions (VLDL, $d<1.006 \mathrm{~g} / \mathrm{ml}$; IDL + LDL, $1.006<d<1.063 \mathrm{~g} / \mathrm{ml}$; and HDL, $1.063<d<1.21 \mathrm{~g} / \mathrm{ml}$ ) were isolated from pooled serum of at least nine fasted mice per group. Isolation was achieved by sequential ultracentrifugation at the respective densities at 40,000 rpm in a Ti-50 fixed-angle rotor (Beckman Instruments, Inc., Geneva, Switzerland) for $18 \mathrm{~h}$ at $5^{\circ} \mathrm{C}$, followed by dialysis at $4^{\circ} \mathrm{C}$ overnight against PBS, $\mathrm{pH}$ 7.4. Protein concentrations in lipoprotein fractions were determined by the method of Lowry et al. (20) with BSA as a standard.

$S D S$-gel electrophoresis and Western blotting. Each lipoprotein fraction was analyzed for apolipoprotein composition by SDS-gel electrophoresis using 4-20\% gradient gels. Proteins were transferred to nitrocellulose membranes (Schleicher and Schuell, Dassel, Germany) followed by incubation with polyclonal rabbit antisera against human apoC1, mouse apoC1, apoB, and apoE. Donkey anti-rabbit ${ }^{125} \mathrm{I}$-IgG (Amersham Corp.) was used as a secondary antibody, and detection was performed by scanning the blots with a Phosphor Imager. Serum of virus-injected mice was collected $2 \mathrm{~d}$ after injection and samples ( $2 \mu$ l per lane) were separated on $4-20 \%$ polyacrylamide gels and the proteins were transferred to nitrocellulose membranes. The membranes were incubated with rabbit antisera against RAP and donkey anti-rabbit ${ }^{125} \mathrm{I}-\mathrm{IgG}$ was used as a secondary antibody. Detection was performed as described above.

Preparation of endogenously labeled VLDL. Fasted mice were anesthetized with an intraperitoneal injection of $0.5 \mathrm{ml} / \mathrm{kg}$ hypnorm (Janssen Pharmaceutica, Tilburg, The Netherlands) and $12.5 \mathrm{mg} / \mathrm{kg}$ midazolam (Roche, Mijdrecht, The Netherlands). Body temperature was maintained with the use of heat lamps. ${ }^{3} \mathrm{H}$-palmitate dissolved in ethanol (Amersham Corp.) was evaporated under nitrogen and redissolved in $0.9 \% \mathrm{NaCl}$ containing $2 \mathrm{mg} / \mathrm{ml} \mathrm{BSA}$. Mice were injected intravenously via the tail vein with $100 \mu \mathrm{Ci}$ of the prepared ${ }^{3} \mathrm{H}$-palmitate and bled from the retroorbital plexus 25 min after injection. Radiolabeled VLDL used for clearance studies was isolated from serum of six mice per group by ultracentrifugation $(d<1.006 \mathrm{~g} / \mathrm{ml})$. The VLDL samples obtained were dialyzed against PBS, $\mathrm{pH} 7.4$, at $4^{\circ} \mathrm{C}$. A sample of endogenously labeled VLDL was subjected to lipid extraction according to Bligh and Dyer (21). The amount of radioactivity in the VLDL-triglyceride fraction was determined after separation of the triglyceride from the other lipid components by TLC on silica gel 60 plates (Merck, Darmstadt, Germany) using hexane:diethylether:acetic acid (83:16:1 by vol) as resolving solution. ${ }^{14} \mathrm{C}$-tripalmitate (Amersham Corp.) was used as an internal standard. In all the VLDL fractions used, $>95 \%$ of the radioactive label was bound to triglyceride.

In vivo turnover studies using ${ }^{3} \mathrm{H}$-triglyceride-labeled $V L D L$

Whole animal. To study the in vivo clearance of labeled VLDL-triglyceride, due to both peripheral lipolysis and hepatic uptake of the remnant particle, fasted mice were anesthetized and injected intravenously with $80,000 \mathrm{dpm}$ of ${ }^{3} \mathrm{H}$-triglyceride-labeled VLDL (autologous injections). The disappearance of the radiolabeled VLDL was determined from $40-\mu \mathrm{l}$ blood samples of mice drawn at time points 
after the injection as indicated. Total serum radioactivity was used to represent VLDL-triglyceride radioactivity, since a pilot study showed that the disappearance of radioactivity as measured after lipid extraction followed by TLC triglyceride analysis did not differ from the disappearance of total serum radioactivity (not shown). The radioactivity at each time point was multiplied by the serum volume of the animal (22) and divided by the injected dose. The data were modeled by a biexponential curve from which the fractional catabolic rate (FCR) was calculated using the reciprocal area under the curve. The secretion rate (SR) was calculated by multiplying the FCR with the serum VLDL-triglyceride pool size as measured in each mouse during the experiment.

Functionally hepatectomized animal. To investigate the in vivo clearance of radiolabeled VLDL due to peripheral lipolysis only, mice were functionally hepatectomized to exclude hepatic VLDLtriglyceride production and uptake (23). Therefore, mice were anesthetized and the hepatic portal vein and the hepatic artery were ligated before injections. ${ }^{3} \mathrm{H}$-triglyceride-labeled VLDL (prepared as described above) was injected and blood samples were drawn and analyzed as described above. The data were kinetically modeled to calculate the lipolytic rate (LR) using the area under the curve. To ensure total exclusion of the liver from the circulation, the liver radioactivity was measured at the end of the experiment using a sample oxidizer (Packard Instrument Co., Meriden, CT). For each hepatectomized mouse used in this study, $<1 \%$ of the injected dose was found in the liver.

In vitro lipolysis. VLDL $(d<1.006 \mathrm{~g} / \mathrm{ml})$, isolated by ultracentrifugation from pooled serum of at least seven fasted mice per group, was incubated at $37^{\circ} \mathrm{C}$ in $0.1 \mathrm{M}$ Tris- $\mathrm{HCl}, \mathrm{pH} 8.5$, for $10 \mathrm{~min}$ with bovine LPL ( 0.2 units, Sigma Chemical Co.) in the presence of $3 \%$ (by wt) BSA (essentially FFA free). The reaction was stopped by the addition of $50 \mathrm{mM} \mathrm{KH}_{2} \mathrm{PO}_{4}, 0.1 \%$ Triton-X 100, $\mathrm{pH} 6.9$, and placed on ice. A blank sample was prepared for each concentration by adding the stop buffer before the LPL, and the difference was regarded as the hydrolyzed amount of VLDL-triglyceride. FFA were measured using an enzymatic colorimetric method as described above. The rate of FFA release by LPL was linear for the $10 \mathrm{~min}$ as used in this assay. The assay was performed on four different concentrations of VLDL $(d<1.006 \mathrm{~g} / \mathrm{ml})$ triglyceride in the range of $0.1-0.4 \mathrm{mM}$ with duplication of FFA determination. Apparent $K_{\mathrm{m}}$ and maximal enzyme activities $\left(\mathrm{V}_{\max }\right)$ for LPL assayed with APOC1 transgenic and control VLDL were calculated from Lineweaver-Burk plots.

In vivo hepatic VLDL-triglyceride production by Triton WR1339 injection. Fasted mice were injected intravenously with Triton WR1339 (500 mg/kg body wt) using 15\% (wt/vol) Triton solution in $0.9 \% \mathrm{NaCl}$. Plasma VLDL clearance is virtually completely inhibited under these circumstances (24). At appropriate time points after injection of Triton (up to $60 \mathrm{~min}$ ), blood samples were drawn. Triglycerides were measured in the serum and related to the body mass of the mice as described above. Production of hepatic triglyceride was calculated from the slope of the curve and expressed as $\mathrm{mmol} / \mathrm{h}$ per $\mathrm{kg}$ body wt.

Adenovirus transfections. The generation of recombinant AdRAP and adenoviral vectors expressing $\beta$-galactosidase (Ad- $\beta$-Gal) under the control of the cytomegalovirus promotor has been described and were kindly provided by Dr. T. Willnow and Dr. J. Herz $(25,26)$. The recombinant adenovirus was propagated and titrated on the Ad5 E1-transformed human embryonic kidney cell line 911 as described (27). Briefly, for large scale production of recombinant adenovirus lots, ten $175-\mathrm{cm}^{2}$ flasks of nearly confluent 911 monolayers were infected with adenovirus at a multiplicity of infection of 5-10 per cell. After 48-60 h, the nearly completely detached cells were harvested and collected in $1 \mathrm{ml}$ PBS/1\% Horse Serum. Virus was released from the producer cells by three rounds of freeze thawing and centrifugation. The lysate was subjected to two rounds of purification by $\mathrm{CsCl}$ centrifugation. The $\mathrm{CsCl}$ was removed from the isolated virus bands by extensive dialysis against TD $(25 \mathrm{mM}$ Tris, $137 \mathrm{mM}$ $\mathrm{NaCl}, 5 \mathrm{mM} \mathrm{KCl}, 0.73 \mathrm{mM} \mathrm{Na}_{2} \mathrm{HPO}_{4}, 0.9 \mathrm{mM} \mathrm{CaCl}_{2}, 0.5 \mathrm{mM} \mathrm{MgCl}$;
$\mathrm{pH} 7.45$ ), at $4^{\circ} \mathrm{C}$. Mouse serum albumin was added to $0.2 \%$ and glycerol to $10 \%$ and the virus stocks were flash frozen in aliquots in liquid $\mathrm{N}_{2}$, and stored at $-80^{\circ} \mathrm{C}$. Routine virus titers of the stocks varied from $1-5 \times 10^{10} / \mathrm{ml}$. For in vivo adenovirus transfection, on day zero, $3.0 \times 10^{9}$ plaque forming units (PFU) in a total volume of $200 \mu \mathrm{l}(\mathrm{di}-$ luted with PBS) were injected into the tail vein of the mice. Blood samples were drawn from the tail vein of fasted mice at 2, 3, and $5 \mathrm{~d}$ after virus injection.

Labeling and activation of $\alpha_{2}$-macroglobulin. Unactivated human $\alpha_{2}$-macroglobulin $\left(\alpha_{2}-\mathrm{M}\right)$ was radioiodinated and activated as described previously (28). In brief, $350 \mu \mathrm{g}$ of $\alpha_{2}$-M was radiolabeled with ${ }^{125} \mathrm{I}$ in the presence of chloramine-T, and after $2 \mathrm{~min}$ the reaction was stopped by addition of $4 \mathrm{mg} / \mathrm{ml} \mathrm{Na}_{2} \mathrm{~S}_{2} \mathrm{O}_{5}$ and $4 \mathrm{mg} / \mathrm{ml} \mathrm{KI} .{ }^{125} \mathrm{I}-\mathrm{\alpha}_{2}-\mathrm{M}$ was directly activated by incubation with a 15 -fold molar excess of trypsin for $5 \mathrm{~min}$, followed by the addition of a fivefold molar excess of soybean trypsin inhibitor relative to trypsin. In a subsequent step, ${ }^{125} \mathrm{I}-\alpha_{2}-\mathrm{M}$ was purified by gel filtration on a $0.7 \times 25 \mathrm{~cm}$ Bio-Gel A- $1.5 \mathrm{~m}$ column (Bio-Rad Laboratories, Richmond, CA) at $4^{\circ} \mathrm{C}$ with PBS, $\mathrm{pH}$ 7.4 , as the eluent.

In vivo turnover studies using ${ }^{125} I-\alpha_{2}$-macroglobulin. $5 \mathrm{~d}$ after injection with either Ad- $\beta-G a l$ or Ad-RAP $\left(3.0 \times 10^{9} \mathrm{PFU}\right)$, mice were anesthetized as described above and injected intravenously via the tail vein with ${ }^{125} \mathrm{I}$-labeled human $\alpha_{2}$-M (5 $\mu \mathrm{g}$ of tracer in $200 \mu \mathrm{l} 0.9 \%$ $\mathrm{NaCl}$ containing $2 \mathrm{mg} / \mathrm{ml} \mathrm{BSA})$. Blood samples $(80 \mu \mathrm{l})$ were collected at the indicated time points and the amount of TCA-precipitable radioactivity in serum was determined as described previously (26).

\section{Results}

Characterization of APOC1 transgenic mice. Two founder mice carrying the human APOC1 construct were characterized. One strain showed low expression for the human APOC1 gene (designated low expressor) in the liver, while another strain showed high liver expression (designated high expressor) for the human APOC1 gene (Fig. 1). As quantified using Northern blotting, hepatic human APOC1 mRNA levels were fourto fivefold elevated in high expressor mice compared with low expressor mice (Table I). In addition, the hepatic mouse Apoc1 mRNA levels of low and high expressor APOC1 transgenic mice were not significantly different from that of control mice, whereas the hepatic mouse Apoe mRNA was slightly but significantly elevated for female high expressor APOC1 transgenic mice (Table I).

Serum lipid levels were measured in fasting APOC1 transgenic and nontransgenic littermates as control mice. When kept on an SRM-A diet, serum triglyceride levels were increased threefold for the male high expressor mice compared with female high expressor, low expressor, and control mice (Table II). In addition, serum cholesterol levels were only slightly elevated in male high expressor mice on a normal chow diet.

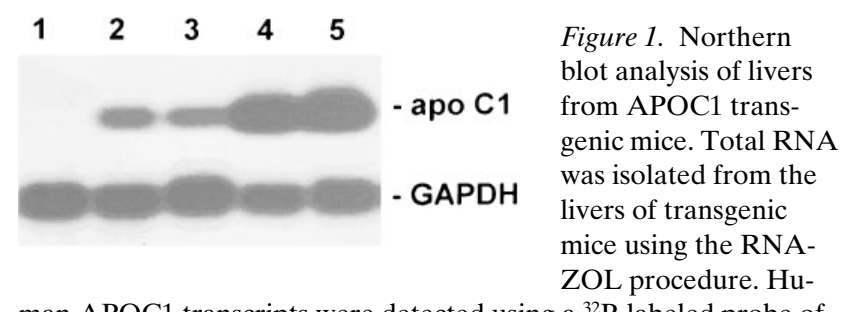

man APOC1 transcripts were detected using a ${ }^{32} \mathrm{P}$-labeled probe of human APOC1 cDNA (13). The autoradiogram was exposed overnight and scanned. Lane 1 , control mice; lane 2, low expressor female mice; lane 3, low expressor male mice; lane 4 , high expressor female mice; and lane 5 , high expressor male mice. 
Table I. Hepatic mRNA Levels in APOC1 Transgenic and Control Mice

\begin{tabular}{lccc}
\hline & \multicolumn{3}{c}{ Hepatic mRNA } \\
\cline { 2 - 4 } \multicolumn{1}{c}{ Mouse strain } & Human APOC1 & Mouse Apoc1 & Mouse Apoe \\
\hline & & percent \\
Control female + male & ND & $100 \pm 13$ & $100 \pm 18$ \\
Low expressor female + male & $100 \pm 43$ & $106 \pm 20$ & $100 \pm 17$ \\
High expressor female & $447 \pm 115^{*}$ & $109 \pm 14$ & $137 \pm 25^{\ddagger}$ \\
High expressor male & $470 \pm 109^{*}$ & $109 \pm 13$ & $110 \pm 18$ \\
& & & \\
\hline
\end{tabular}

Livers were isolated from fasted mice on the LFC diet to quantify mRNA. mRNA concentrations (means \pm SD of six livers per group) are relative to internal standard GAPDH. Values are expressed as a percentage of low expressor mice (human APOC1) or control mice (mouse Apoc1 and Apoe). ND, not detectable. ${ }^{*} P<0.05$, indicating the difference between low and high expressor APOC1 transgenic mice, using nonparametric Mann-Whitney tests; and ${ }^{\ddagger} P<0.05$, indicating the difference between control and APOC1 transgenic mice.

To investigate the response of the APOC1 transgenic mice to a sucrose-rich diet, which is known to stimulate hepatic VLDL-triglyceride production (17), mice were fed an LFC diet containing $50.5 \%$ sucrose. After 3 wk on the LFC diet, there was no significant difference in serum triglyceride and cholesterol levels among control and low expressor mice (Table II). As determined by FPLC, almost all of the serum cholesterol in control and low expressor mice was confined to the HDL-sized fractions (results not shown). On this LFC diet, female high expressor mice showed significantly elevated levels of serum cholesterol and triglyceride compared with control mice, whereas both cholesterol and triglyceride levels were strongly elevated in male high expressor mice (Table II). This increment in serum cholesterol and triglyceride for high expressor APOC1 transgenic mice was confined to the VLDLsized fractions (results not shown).

We further compared low and high expressor APOC1 transgenic and control mice regarding their response to cholesterol feeding. After $3 \mathrm{wk}$ on the HFC diet $(0.25 \%$ cholesterol plus $15 \%$ cocoa butter, by wt), total serum cholesterol levels were increased among all groups compared with the LFC and SRM-A diets, but most pronounced in male high expressor
Table III. Lipid Composition of Serum Lipoproteins in APOC1 Transgenic and Control Mice

\begin{tabular}{|c|c|c|c|c|c|c|}
\hline \multirow[b]{2}{*}{ Mouse strain } & \multirow{2}{*}{$\begin{array}{l}\text { Serum density } \\
\quad \text { fraction }\end{array}$} & \multicolumn{5}{|c|}{ Lipid composition } \\
\hline & & TG & $\mathrm{TC}$ & FC & $\mathrm{CE}$ & PL \\
\hline & $g / m l$ & & umol & $l / m g p r$ & rotein & \\
\hline \multirow[t]{3}{*}{ Control } & $d<1.006$ & 3.24 & 0.86 & 0.71 & 0.15 & 0.66 \\
\hline & $1.006<d<1.063$ & 0.21 & 3.37 & 1.02 & 2.35 & 1.42 \\
\hline & $1.063<d<1.21$ & 0.01 & 1.05 & 0.15 & 0.89 & 0.36 \\
\hline \multirow[t]{3}{*}{ High expressor female } & $d<1.006$ & 5.14 & 2.31 & 1.32 & 1.00 & 2.06 \\
\hline & $1.006<d<1.063$ & 0.83 & 3.08 & 0.93 & 2.15 & 1.75 \\
\hline & $1.063<d<1.21$ & 0.01 & 1.24 & 0.20 & 1.04 & 0.40 \\
\hline \multirow[t]{3}{*}{ High expressor male } & $d<1.006$ & 6.86 & 4.12 & 1.88 & 2.24 & 2.87 \\
\hline & $1.006<d<1.063$ & 0.66 & 3.05 & 0.82 & 2.23 & 1.97 \\
\hline & $1.063<d<-1.21$ & 0.01 & 1.15 & 0.19 & 0.96 & 0.81 \\
\hline
\end{tabular}

Lipid levels were measured in lipoprotein fractions, derived from pooled serum of at least nine fasted mice per group on the LFC diet, as described in Methods. TG, triglyceride; TC, total cholesterol; FC, free cholesterol; CE, cholesterol ester; PL, phospholipid.

mice (Table II). Serum triglyceride levels in high expressor mice were lowered on the HFC diet compared with the LFC and SRM-A diets, a phenomenon previously described for APOE*3Leiden-APOC1 transgenic mice $(18,29,30)$.

Effects of APOC1 overexpression on the composition of the individual lipoprotein fractions. To investigate whether the effect of APOC1 overexpression on serum lipid levels was accompanied by a change in the lipid and apolipoprotein composition of the different lipoprotein fractions, the respective lipoproteins from high expressor female and male APOC1 transgenic and control mice on the LFC diet were isolated by sequential ultracentrifugation. The relative lipid composition of the individual lipoprotein fractions are shown in Table III. In the APOC1 transgenic mice, the $d<1.006 \mathrm{~g} / \mathrm{ml}$ fractions were enriched in total cholesterol, both free and esterified cholesterol, as compared with the $d<1.006 \mathrm{~g} / \mathrm{ml}$ fraction of control mice. Furthermore, the $d<1.006 \mathrm{~g} / \mathrm{ml}$ and $1.006<d<$ $1.063 \mathrm{~g} / \mathrm{ml}$ fractions of APOC1 transgenic mice were enriched in triglyceride as compared with control mice. No clear differences between the groups were observed in the $1.063<d<$ $1.21 \mathrm{~g} / \mathrm{ml}$ fractions.

Table II. Serum Lipid Levels in APOC1 Transgenic and Control Mice

\begin{tabular}{|c|c|c|c|c|c|c|}
\hline \multirow[b]{3}{*}{ Mouse strain } & \multicolumn{6}{|c|}{ Diet } \\
\hline & \multicolumn{2}{|c|}{ SRM-A } & \multicolumn{2}{|c|}{ LFC } & \multicolumn{2}{|c|}{$\mathrm{HFC}$} \\
\hline & TC & TG & TC & TG & $\mathrm{TC}$ & TG \\
\hline & \multicolumn{6}{|c|}{ mmol/liter } \\
\hline Control female + male & $2.1 \pm 0.3$ & $0.4 \pm 0.2$ & $2.7 \pm 0.1$ & $0.4 \pm 0.1$ & $2.9 \pm 0.5$ & $0.2 \pm 0.1$ \\
\hline Low expressor female + male & $2.1 \pm 0.2$ & $0.4 \pm 0.1$ & $2.7 \pm 0.3$ & $0.6 \pm 0.2$ & $3.7 \pm 0.3^{*}$ & $0.2 \pm 0.1$ \\
\hline High expressor female & $2.1 \pm 0.4$ & $0.5 \pm 0.1$ & $3.0 \pm 0.1 *$ & $0.7 \pm 0.1 *$ & $4.4 \pm 0.6^{*}$ & $0.4 \pm 0.1$ \\
\hline High expressor male & $3.6 \pm 0.7 * \neq$ & $1.5 \pm 0.6^{* \ddagger}$ & $5.7 \pm 0.7 * \ddagger$ & $3.3 \pm 2.1 * \ddagger$ & $7.5 \pm 1.4 * \ddagger$ & $1.0 \pm 0.3^{* *}$ \\
\hline
\end{tabular}

Total cholesterol (TC) and triglyceride (TG) values were measured in serum of control and APOC1 transgenic mice fed an SRM-A, an LFC, or an $\mathrm{HFC}$ diet for a period of $3 \mathrm{wk}$. Values are expressed as the means $\pm \mathrm{SD}$ of at least seven mice per group. $* P<0.05$, indicating the difference between control and APOC1 transgenic mice on the same diet; and ${ }^{\ddagger} P<0.05$, indicating the difference between low expressor and high expressor APOC1 transgenic mice on the same diet, using nonparametric Mann-Whitney tests. 


\section{A $\mathrm{d}<1.006 \mathrm{~g} / \mathrm{ml}$}

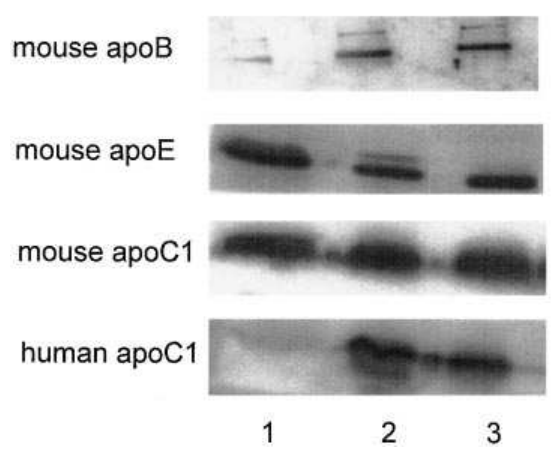

B $1.006<\mathrm{d}<1.063 \mathrm{~g} / \mathrm{ml}$
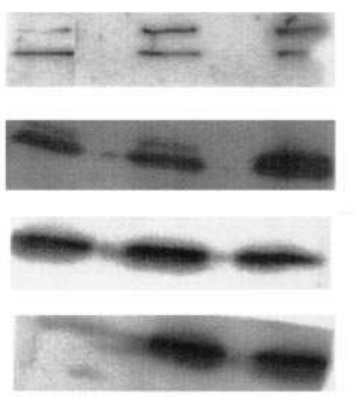

1
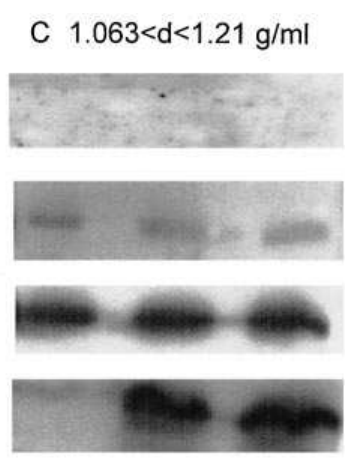

3
Figure 2. Apolipoprotein composition of VLDL by Western blotting. The individual lipoprotein fractions $(A$, VLDL; $B$, IDL-LDL; and $C$, HDL) were isolated by sequential ultracentrifugation at the respective densities. $7 \mu \mathrm{g}$ of VLDL-protein from control mice (lane 1), female high expressor APOC1 transgenic mice (lane 2), and male high expressor mice (lane 3) was subjected to SDS-gel electrophoresis (4-20\% gradient gels) and transferred to a nitrocellulose membrane. The membrane was

incubated with polyclonal antisera against mouse apoB (upper band, apoB100; lower band, apoB48), mouse apoE, mouse apoC1, and human apoC1. Donkey anti-rabbit ${ }^{125} \mathrm{I}-\mathrm{IgG}$ was used as a secondary antibody and detection was performed by scanning the blots with a Phosphor Imager.

The effect of the high expression levels of transgenic human APOC1 on the apolipoprotein composition of the different lipoprotein fractions was investigated by immunoblot analysis (Fig. 2). APOC1 transgenic mice accumulate mainly apoB48-containing particles, whereas there was a small increase in apoB100 particles. The $d<1.006 \mathrm{~g} / \mathrm{ml}$ fractions of APOC1 transgenic mice clearly showed a decrease in the amount of mouse apoE (Fig. $2 A$ ). No differences were observed in the apoE content on the other lipoprotein fractions (Fig. 2, $B$ and $C$ ). Furthermore, the lipoprotein fractions of all groups contained similar amounts of mouse apoC1, whereas human apoC1 was present on all lipoprotein fractions of the APOC1 transgenic mice, as expected.

$V L D L$-triglyceride turnover studies in APOC1 transgenic and control mice. To investigate the mechanisms underlying the hypertriglyceridemia in APOC1 transgenic mice, VLDLtriglyceride turnover studies were performed. Before these experiments, all mice were fed a sucrose-containing LFC diet,

A

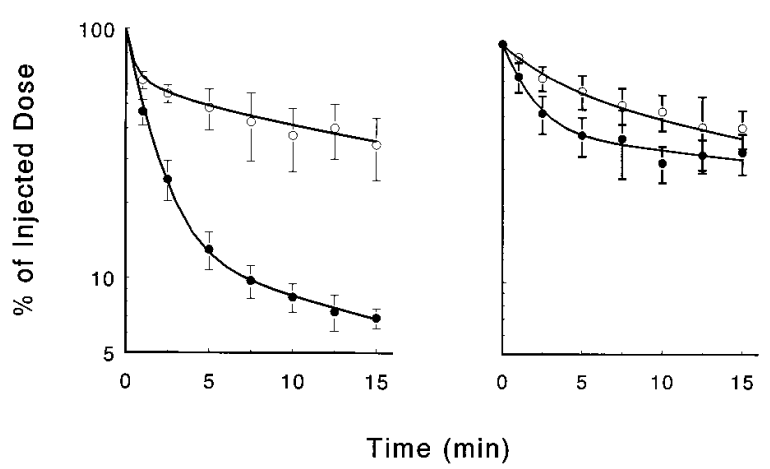

Figure 3. Clearance of labeled VLDL in APOC1 transgenic and control mice. 80,000 dpm of in vivo-labeled ${ }^{3} \mathrm{H}-\mathrm{VLDL}$ triglyceride was injected intravenously into fasted mice on the LFC diet $(A)$ or in mice that were functionally hepatectomized $(B)$ before injection. The disappearance of the labeled VLDL was followed in time by counting the serum radioactivity expressed as a percentage of the injected dose. Values are the mean \pm SD for six male control mice $(\bullet)$ and six male high expressor APOC1 transgenic mice $(\bigcirc)$. The curves were calculated from the mean data using a biexponential curve fit model. since the hypertriglyceridemia in APOC1 transgenic mice was most pronounced on this diet (Table II).

Turnover studies were performed in male high expressor APOC1 transgenic mice and in male control mice that were matched for age. Endogenously labeled VLDL $(d<1.006 \mathrm{~g} /$ $\mathrm{ml}$ ) was isolated from serum collected from mice $25 \mathrm{~min}$ after injection of ${ }^{3} \mathrm{H}$-palmitate. After autologous injection, the labeled VLDL-triglyceride was cleared at a reduced rate in high expressor mice compared with control mice (Fig. $3 A$ ). From these data, the FCR and SR were calculated (Table IV). In high expressor mice, the VLDL FCR was significantly decreased as compared with that in control mice (3.2 \pm 1.8 vs. $13.7 \pm 2.9$ pools $/ \mathrm{h})$.

As presented in Table IV, male high expressor mice displayed an elevated VLDL SR, but not significantly different from that of control mice $(0.26 \pm 0.16 \mathrm{vs} .0 .11 \pm 0.03 \mathrm{mmol} / \mathrm{h}$ per $\mathrm{kg}$ ). Since the VLDL SR was estimated indirectly by bi-exponential curve fitting of turnover data, the in vivo VLDL-triglyceride production rate in APOC1 transgenic and control mice was measured more directly by injecting mice with Triton WR1339. This direct assessment revealed no differences in both groups of mice with respect to VLDL-triglyceride pro-

Table IV. VLDL-triglyceride Fractional Catabolic, Secretion, Production, and Lipolytic Rates for APOC1 Transgenic and Control Mice

\begin{tabular}{lcccc}
\hline Mouse strain & FCR & SR & PR & LR \\
\hline & pools $/ h$ & mmol/h per kg & mmol/h per kg & pools $/ h$ \\
Control & $13.7 \pm 2.9$ & $0.11 \pm 0.03$ & $0.23 \pm 0.04$ & $3.30 \pm 1.46$ \\
High expressor & $3.2 \pm 1.8^{*}$ & $0.26 \pm 0.16$ & $0.32 \pm 0.08$ & $2.24 \pm 0.62$
\end{tabular}

FCR were calculated from the in vivo clearance studies of labeled autologous VLDL in six male high expressor APOC1 transgenic and six male control mice (Fig. $3 \mathrm{~A}$ ). From these data, the SR were calculated by multiplying the FCR with the pool size. The hepatic VLDL-triglyceride production rate (PR) was measured by injecting five transgenic and five control mice with Triton WR1339. LR were calculated from the in vivo clearance of labeled VLDL in six hepatectomized transgenic and six control mice (Fig. 3 B). Values are expressed as the means \pm SD. $* P<$ 0.05 , indicating the difference between high expressor APOC1 transgenic and control mice, using nonparametric Mann-Whitney tests. 
Table V. Serum Lipid Levels in APOC1 Transgenic and Control Mice Before and After the Intravenous Administration of Heparin

\begin{tabular}{lccccc}
\hline \multirow{2}{*}{ Mouse strain } & \multicolumn{2}{c}{ Preheparin } & & \multicolumn{2}{c}{ Postheparin } \\
\cline { 2 - 3 } \cline { 6 - 7 } & TG & TC & & TG & TC \\
\hline Control & $0.62 \pm 0.21$ & $2.52 \pm 0.08$ & & $0.16 \pm 0.02$ & $2.12 \pm 0.35$ \\
High expressor & $1.81 \pm 0.74$ & $5.19 \pm 0.68$ & & $0.35 \pm 0.05$ & $4.11 \pm 0.66$
\end{tabular}

Fasting male APOC1 transgenic and control mice were administered heparin at $5 \mathrm{IU} / 30 \mathrm{~g}$ body wt by injection into the tail vein. Serum was collected $15 \mathrm{~min}$ after injection and total cholesterol (TC) and triglyceride (TG) levels were measured (see Methods). All values are expressed as the means $\pm \mathrm{SD}$ of five mice per group.

duction (Table IV), although the values were higher than those calculated from the turnover data $(0.32 \pm 0.08$ vs. $0.23 \pm 0.04 \mathrm{mmol} / \mathrm{h}$ per $\mathrm{kg}$ ).

To investigate whether the decreased FCR of VLDL-triglyceride in APOC1 transgenic mice is due to a disturbed extrahepatic lipolysis, rather than a defective hepatic uptake, control and high-expressor APOC1 transgenic mice were functionally hepatectomized to rule out VLDL-triglyceride clearance via the liver lipoprotein receptors. In vivo clearance of VLDL-triglyceride in the extrahepatic circulation was similar for APOC1 transgenic and control mice (Fig. $3 B$ ). By calculating the LR from these experiments, no significant difference could be observed between high expressor APOC1 transgenic and control mice (Table IV).

The administration of heparin, which releases lipase activity into the plasma, resulted in a five- and fourfold decrease in serum triglyceride for APOC1 transgenic and control mice, respectively (Table V). These results suggest that the suitability of VLDL as substrate for LPL in APOC1 transgenic mice is not significantly affected by the high levels of apoC1.

To further investigate if impaired hydrolysis of serum triglyceride might contribute to the observed elevated levels of triglyceride in APOC1 transgenic mice, VLDL $(d<1.006 \mathrm{~g} /$ $\mathrm{ml}$ ) was isolated from pooled serum of high expressor male APOC1 transgenic and control mice, and the suitability as substrate for bovine LPL was investigated (Table VI). Lineweaver-Burk plot analysis revealed no differences between the APOC1 transgenic and control VLDL samples in both the apparent $K_{\mathrm{m}}$ and $\mathrm{V}_{\max }$ values. These results indicate that the

Table VI. Apparent Kinetic Parameters of VLDL for LPL-mediated Lipolysis In Vitro

\begin{tabular}{lcc}
\hline \multicolumn{1}{c}{ VLDL } & $K_{\mathrm{m}}$ & $\mathrm{V}_{\max }$ \\
\hline & mmol TG/liter & mmol FFA/liter per min \\
Control & $0.15 \pm 0.06$ & $0.24 \pm 0.14$ \\
High expressor & $0.19 \pm 0.12$ & $0.20 \pm 0.15$ \\
\hline
\end{tabular}

Apparent kinetic parameters for serum VLDL preparations $(d<1.006$ $\mathrm{g} / \mathrm{ml}$ ) of high expressor male APOC1 transgenic and control mice. Values were calculated from Lineweaver-Burk plots and are given as means \pm SD of four independent experiments with VLDL isolated from four different pools of serum (at least 10 mice per group). TG, triglyceride.
Table VII. Serum Lipid Levels in APOC1/LDLR-deficient Mice and Adenovirus-RAP Injection

\begin{tabular}{|c|c|c|c|c|c|c|}
\hline \multirow[b]{3}{*}{ Mouse strain } & \multicolumn{6}{|c|}{ Ad-RAP injection } \\
\hline & \multicolumn{3}{|c|}{ Before } & \multicolumn{3}{|c|}{ After } \\
\hline & $\mathrm{N}$ & $\mathrm{TC}$ & TG & $\mathrm{N}$ & $\mathrm{TC}$ & TG \\
\hline & \multicolumn{4}{|c|}{$\mathrm{mmol} /$ liter } & \multicolumn{2}{|c|}{$\mathrm{mmol} /$ liter } \\
\hline Wild-type & 10 & $2.2 \pm 0.1$ & $0.4 \pm 0.2$ & 5 & $3.1 \pm 0.6$ & $2.2 \pm 0.3$ \\
\hline APOC1 & 10 & $3.6 \pm 0.4$ & $1.7 \pm 0.4$ & 5 & $7.1 \pm 3.7$ & $11 \pm 9$ \\
\hline $\mathrm{LDLR}^{+/-}$ & 6 & $4.6 \pm 0.8$ & $0.2 \pm 0.1$ & & & - \\
\hline $\mathrm{LDLR}^{+/-} / \mathrm{APOC} 1$ & 10 & $10 \pm 4$ & $3.0 \pm 2.2$ & & & - \\
\hline $\mathrm{LDLR}^{-/-}$ & 9 & $8.4 \pm 0.9$ & $0.5 \pm 0.2$ & 5 & $39 \pm 8$ & $17 \pm 8$ \\
\hline $\mathrm{LDLR}^{-/-} / \mathrm{APOC} 1$ & 18 & $52 \pm 19$ & $36 \pm 19$ & 5 & $60 \pm 10$ & $38 \pm 7$ \\
\hline
\end{tabular}

High expressor APOC1 transgenic mice were mated with LDLR-deficient $\left(\mathrm{LDLR}^{-1-}\right)$ mice to obtain mice heterozygous $\left(\mathrm{LDLR}^{+-}\right)$or homozygous (LDLR ${ }^{--}$) for the LDLR defect with or without APOC1 overexpression. Total serum cholesterol (TC) and triglyceride (TG) levels of fasted male mice on a normal chow diet were measured before, and $5 \mathrm{~d}$ after Ad-RAP $\left( \pm 3 \times 10^{9} \mathrm{PFU}\right)$ injection. $(\mathrm{N}=$ number of mice, mean $\pm \mathrm{SD} ;-$, not performed $)$. Injection with Ad- $\beta$-Gal $\left( \pm 3 \times 10^{9}\right.$ PFU) did not affect serum lipid levels in wild-type and $\mathrm{LDLR}^{-1-}$, APOC1 mice. RAP was detected in serum of Ad-RAP injected mice, $2 \mathrm{~d}$ after injections, using SDS-gel electrophoresis followed by Western blotting using rabbit anti-RAP as first antibody.

presence of excess apoC1 on the VLDL particle does not influence the lipolysis of VLDL-triglyceride.

APOC1 overexpression in combination with $L D L$-receptor deficiency. To determine whether apoC1-enriched VLDL shows impaired binding to hepatic receptors other than the LDLR, high expressor APOC1 transgenic mice were mated with LDLR-deficient (LDLR ${ }^{-/}$) mice. The serum lipid levels in all groups are shown in Table VII. Total serum cholesterol in wild-type mice, having both functional alleles for the LDLR, was confined to the HDL-sized fractions (Fig. $4 A$ ), whereas high expression of APOC1 in these mice showed elevated levels of serum cholesterol and triglyceride that were mainly confined to the VLDL-sized fractions (Fig. $4 \mathrm{~B}$ ). Mice heterozygous for the LDLR defect $\left(\mathrm{LDLR}^{+-}\right)$showed elevated levels of cholesterol compared with wild-type mice, whereas serum triglyceride levels were not different. FPLC patterns showed that this increase in serum cholesterol was due to an accumulation of IDL/LDL-sized particles in the circulation (Fig. $4 \mathrm{C}$ ). Overexpression of APOC1 leads to a further increase of both serum cholesterol and triglyceride in these heterozygous LDLR-deficient mice that was confined to the VLDL/IDLsized fractions (Fig. $4 \mathrm{D}$ ). Mice homozygous for the LDLR defect showed increased levels of cholesterol but not triglyceride. Overexpression of APOC1 in these mice caused a dramatic increase of both serum cholesterol and triglyceride. FPLC patterns showed that the increase of cholesterol in $\mathrm{LDLR}^{-1-}$ mice is confined to the IDL/LDL-sized fractions (Fig. $4 E$ ), whereas overexpression of APOC1 in these mice caused a massive accumulation of VLDL-containing cholesterol and triglyceride (Fig. $4 F$ ). These results indicate that when the LDLR is absent, overexpression of APOC1 has a pronounced inhibiting effect on the clearance of VLDL-sized lipoproteins via an alternative clearance pathway. 

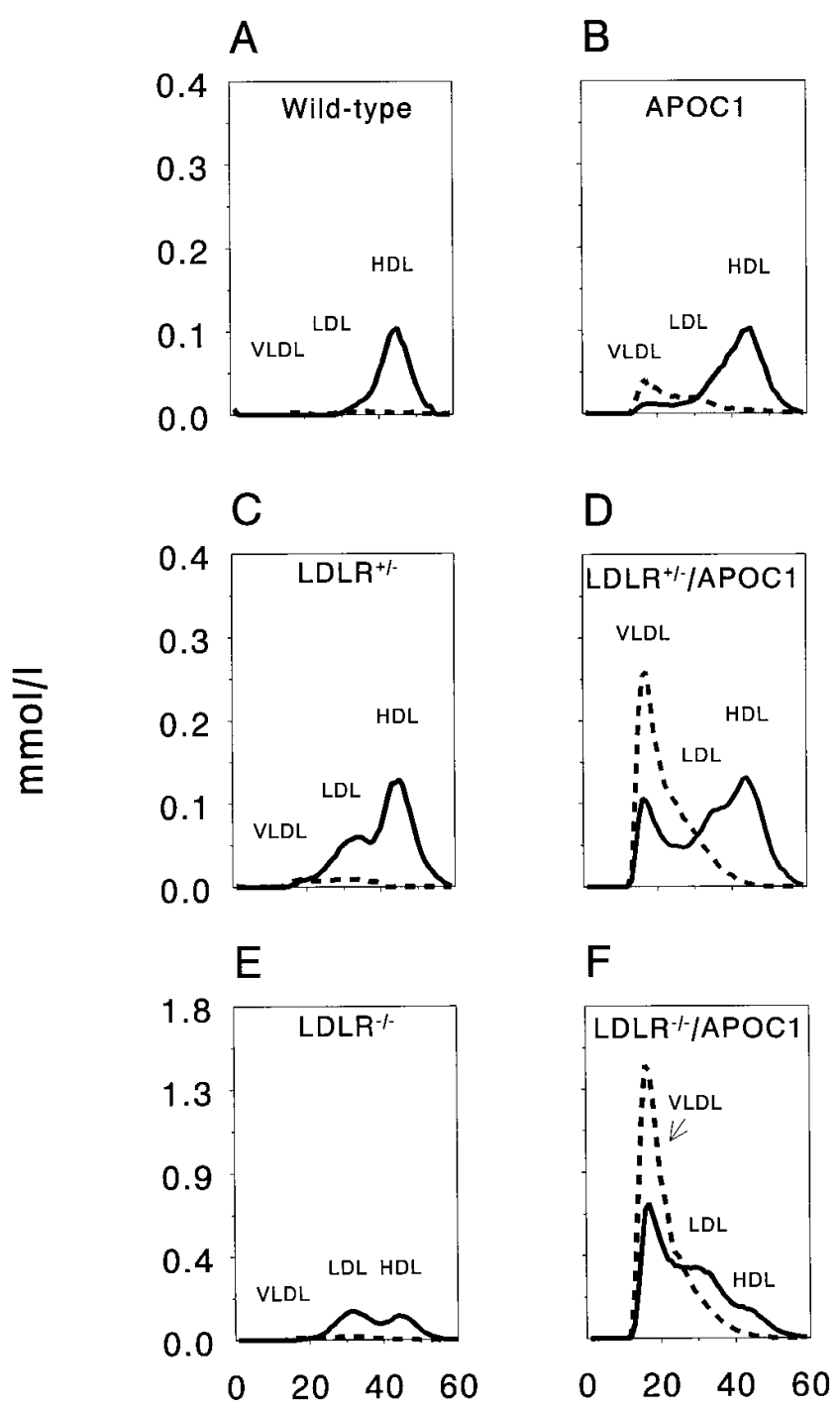

\section{Fraction number}

Figure 4. Lipoprotein profiles. Sera from at least seven fasted control mice $(A)$, APOC1 mice $(B), \mathrm{LDLR}^{+/-}$mice $(C), \mathrm{LDLR}^{+/-} / \mathrm{APOC} 1$ mice $(D), \mathrm{LDLR}^{-1-}$ mice $(E)$, and $\mathrm{LDLR}^{-1-} / \mathrm{APOC} 1$ mice $(F)$ were pooled and separated on the basis of size by FPLC. Mice were fed the chow diet. The cholesterol (solid line) and triglyceride (dotted line) content of each individual fraction was measured enzymatically as described above. Note the difference in scale of $E$ and $F$ relative to $A-D$. Fractions 10-25 represent VLDL, fractions 25-40 represent IDL/LDL, and fractions 40-50 represent HDL.

Adenovirus-mediated transfection of mice with RAP $c D N A$. To investigate whether apoC1-enriched VLDL shows impaired binding to a RAP-sensitive pathway, RAP was overexpressed via injection of recombinant Ad-RAP cDNA in wild-type, APOC1 transgenic, $\mathrm{LDLR}^{-/-}$, and $\mathrm{LDLR}^{-/-}$/ APOC1 mice. Ad- $\beta-$ Gal injections were used as a control. It has been shown previously that injection of Ad-RAP efficiently blocks ligand clearance via the LRP (25). To determine whether in the present study Ad-RAP transfection completely blocked ligand clearance via the LRP, ${ }^{125} \mathrm{I}-\alpha_{2}$-macroglobulin turnover studies were performed. $5 \mathrm{~d}$ after Ad-RAP transfection, Ad-RAP-injected mice, but not Ad- $\beta$-Gal-injected mice,

were unable to clear ${ }^{125} \mathrm{I}-\alpha_{2} \mathrm{M}$ from their circulation (Fig. 5). $5 \mathrm{~d}$ after Ad-RAP injections, wild-type mice showed slightly elevated serum cholesterol and triglyceride levels compared with the not injected wild-type mice, similar to the lipid values of APOC1 transgenic mice (Table VII). Transfection of APOC1 transgenic mice with Ad-RAP further increased serum cholesterol and triglyceride levels. Treatment of $\mathrm{LDLR}^{-1-}$ mice with Ad-RAP strongly increased both serum cholesterol and triglyceride. However, in the extremely hyperlipidemic $\mathrm{LDLR}^{-1-}$ / APOC1 mice, the transfection with Ad-RAP did not result in a further increase in serum cholesterol and triglyceride levels (Table VII).

\section{Discussion}

In the present study, we report the generation of two different APOC1 transgenic mouse lines with low and high expression of the transgene. These mice show elevated levels of serum cholesterol and triglyceride, which were positively correlated with the level of expression of the transgene. In vivo turnover studies revealed that the clearance of VLDL-triglyceride was reduced in APOC1 transgenic mice. Since in vitro, VLDL samples of APOC1 transgenic mice were as good as a substrate for bovine LPL as VLDL samples from control mice, and both the in vivo extrahepatic lipolysis rate and production rate of APOC1 VLDL-triglyceride were not significantly different from control mice, an impaired hepatic uptake of VLDL remnants seems to be the primary catabolic defect in APOC1 transgenic mice.

These results are in line with recent studies by our group, in which APOE*3Leiden transgenic mice overexpressing human APOC1 simultaneously show enhanced hypertriglyceridemia as compared with APOE*3Leiden transgenic mice without coexpression of the APOC1 transgene (30). In vivo turnover studies indicated that in the hyperlipidemic APOE*3Leiden mice, APOC1 expression leads to a further decrease in hepatic clearance of VLDL-triglyceride, without affecting peripheral lipolysis.

Apolipoprotein analysis by SDS-PAGE and immunoblotting revealed that increased amounts of human APOC1 on VLDL of APOC1 transgenic mice was accompanied by a decrease in apoE. Previous studies showed that hypertriglyceridemia in transgenic mice overexpressing the human APOC3 or APOC2 gene $(24,31)$ is caused by an impaired hepatic up-

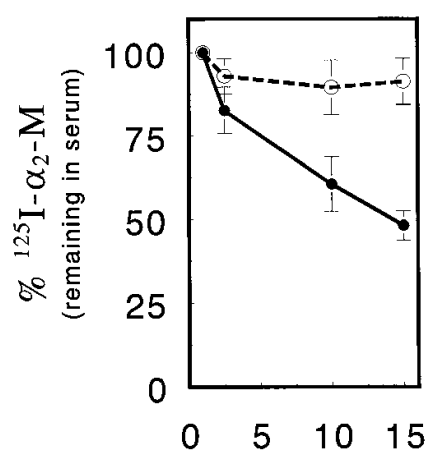

Time $(\mathrm{min})$
Figure 5. ${ }^{125} \mathrm{I}-\alpha_{2}-\mathrm{macroglobu}-$ lin clearance. Human $\alpha_{2}$-M was activated and labeled as described in Methods. $5 \mathrm{~d}$ after $\mathrm{LDLR}^{-1-}$ mice had been transfected with Ad- $\beta$-Gal (solid line) or Ad-RAP (dotted line), ${ }^{125} \mathrm{I}-\alpha_{2}$-M was injected intravenously via the tail vein. The dissappearance of the label was followed in time by counting the TCA-precipitable radioactivity in serum and expressed as the percentage of radioactivity present at $1 \mathrm{~min}$. Values are the mean \pm SD of five mice per group. 
take of VLDL, concomitant with a decreased VLDL apoE/ apoC ratio. In line with this, crossbreeding of APOC3 transgenic mice with APOE overexpressing mice resulted in normal levels of plasma triglyceride (32). Similarly, transgenic mice overexpressing the human APOC1 and APOE gene simultaneously showed normal lipid levels (9). Thus, these studies and our present study indicate that overexpression of all three $\mathrm{C}$ apolipoproteins impair the hepatic clearance of remnant lipoproteins in vivo, most probably as a consequence of low amounts of apoE relative to the $\mathrm{C}$ apolipoprotein.

Recently, we found that simultaneous expression of APOC1 in $\mathrm{APOE}^{*} 3 \mathrm{Leiden}$ transgenic mice further inhibits the hepatic uptake of VLDL without displacing apoE (30). In line with these results, previous in vitro studies showed that triglyceriderich particles enriched with apoC1 are cleared less efficiently by perfused rat livers than control particles, independent of the amount of apoE on the particle $(4,5)$. Whether the observed hyperlipidemia in APOC1 transgenic mice substantially reflects the specific inhibitory effect on hepatic particle uptake of apoC1 by conformational changes of apoE, or the displacement of apoE, is subject to further investigations.

Previous studies showed that pretreatment with an antiLDLR antibody reduced in vivo hepatic remnant uptake in wild-type mice up to $50 \%$ (33), whereas activated $\alpha_{2}-\mathrm{M}$ and RAP injections reduced remnant uptake by only $15 \%$ (34). From these studies it was concluded that under normal conditions the LDLR plays a substantially greater role in the removal of remnant particles than LRP. Thus, since LRP seems relatively inefficient under normal condition, the mild increase in serum cholesterol and triglyceride levels with APOC1 overexpression may be reflected by partial inhibition of the LDLR. This is in line with in vitro studies by Sehayek and Eisenberg (6), showing that apoC1 impairs the apoE-mediated binding to the LDLR. However, it was reported by Weisgraber et al. (7) that apoC1 inhibits the apoE-mediated binding to LRP. To discriminate which receptor is predominantly inhibited in binding VLDL by an excess of apoC1 in vivo, APOC1 transgenic mice were bred with an LDLR-deficient ( $\mathrm{LDL}^{-/}$) background and RAP was overexpressed through transfection with adenovirus containing Ad-RAP. LDLR $^{-1-}$ mice accumulate significant amounts of LDL in their plasma with little or no accumulation of triglyceride (remnants) (35). Thus the alternative pathway (LRP) provides a backup mechanism for the clearance of remnants when the LDLR is genetically deficient. In the present study, overexpression of APOC1 in these $\mathrm{LDLR}^{-1-}$ mice causes a massive further accumulation of VLDL cholesterol and triglyceride in the circulation, indicating that apoC1 in the absence of the LDLR has a pronounced inhibiting effect on the uptake of VLDL via an alternative clearance pathway.

Recently, considerable interest has been given to the LRP as an alternate receptor for hepatic uptake of remnant lipoproteins $(36,37)$. Structurally, the LRP is closely related to the LDLR and it can bind apoE-enriched remnant lipoproteins (38). RAP, a 39-kD polypeptide that is suggested to stabilize LRP within the secretory pathway, when added extracellularly inhibits the binding of all known ligands to this receptor (39). Studies by Willnow et al. (25) showed that overexpression of RAP via adenovirus-mediated transfection in $\mathrm{LDLR}^{-1-}$ mice resulted in a marked accumulation of remnants in these mice. These data indicate that in vivo remnant clearance is achieved via a RAP-sensitive receptor pathway, most likely the LRP pathway. To investigate whether apoC1-enriched VLDL in vivo shows impaired binding to the LRP, or possibly other receptors sensitive to RAP, RAP was overexpressed in wildtype, APOC1 transgenic, $\mathrm{LDLR}^{-/-}$, and $\mathrm{LDLR}^{-/-} / \mathrm{APOC} 1$ transgenic mice by Ad-RAP transfection. Ad-RAP transfection in wild-type mice slightly increased both serum cholesterol and triglyceride levels (Table VII). Since RAP binds weakly to the LDLR, Willnow et al. (25) proposed that this mild accumulation of remnants in Ad-RAP-injected wild-type mice was probably due to a partial inhibition of the LDLR at high RAP expression levels in addition to the total block of the alternative remnant clearance pathway. The further elevation in serum cholesterol and triglyceride observed in Ad-RAPtransfected APOC1 transgenic mice might therefore also be explained by partial blockage of the LDLR by RAP. However, the observation that Ad-RAP transfection greatly enhanced serum cholesterol and triglyceride levels in $\mathrm{LDLR}^{-1-}$ mice, whereas it had no additional effect on serum lipid levels in LDLR $^{-/-}$APOC1 mice, lets us conclude that RAP and APOC1 overexpression act on the same pathway in inhibiting the clearance of VLDL remnants by the liver. Since under these conditions the clearance of $\alpha_{2}$-macroglobulin (as a ligand for LRP) was completely inhibited, apoC1 inhibition most likely acts upon the LRP pathway, at least in the absence of the LDLR.

In the present study, LDLR deficiency resulted in the elevation of serum cholesterol only, whereas both APOC1 and RAP overexpression had a pronounced effect on the elevation of serum triglyceride as well. Therefore, we cannot exclude that the mild phenotype in APOC1 transgenic mice in the presence of the LDLR may also be due to an inhibition of the alternative pathway (LRP). Further research is neccesary to estimate the exact contributions of the two receptor pathways in remnant clearance.

In homozygous $\mathrm{LDLR}^{-/-}$mice, the expression of the RAP gene causes a less severe hyperlipidemia than overexpression of the APOC1 gene in these mice (Table VII). Therefore, next to its inhibitory effect on LRP, an effect of apoC1 on serum VLDL metabolism through other mechanisms cannot be ruled out. It has previously been shown that VLDL isolated from hypertriglyceridemic apoC2 transgenic mice is defective in its interaction with heparin-Sepharose (31), suggesting that apoC2 overexpression may hamper the interaction of VLDL with cell surface proteoglycans. Whether apoC1 interferes in vivo with the binding of lipoproteins to heparan sulfate proteoglycans, and thereby hampers the enrichment of lipoproteins with surface-bound apoE thought to be involved in the hepatic uptake of VLDL remnants by the LDLR or LRP (40), needs to be further adressed. In addition, APOC1 transgenic mice show a tendency towards enhanced hepatic VLDL production (Table IV), which could also explain the more severe hyperlipidemia in $\mathrm{LDLR}^{-1-} / \mathrm{APOC} 1$ mice compared with Ad-RAP-injected $\mathrm{LDLR}^{-1-}$ mice.

In summary, transgenic mice overexpressing human APOC1 are hyperlipidemic due to an impaired hepatic clearance of VLDL from the circulation. At least in the absence of the LDLR, this appears to be the result of an inhibition by apoC1 of VLDL clearance through RAP-sensitive pathways, like the LRP, whereas an effect on other processes in VLDL metabolism cannot be excluded. Although a role for apoC1 in human disease remains to be established, APOC1 transgenic mice are an instructive model of hypertriglyceridemia and elucidate a 
possible mechanism of how $\mathrm{C}$ apolipoproteins act upon lipoprotein metabolism.

\section{Acknowledgments}

We are grateful to Dr. Thomas Willnow and Dr. Joachim Herz for providing the adenovirus containing RAP cDNA. We thank Hans van der Boom and André van der Zee for excellent technical assistance, Rob Houben and Frits Fallaux for technical advice, and Ingeborg Nieuwenhuizen and Ilma Rietbroek for animal care.

This research was supported by the Netherlands Heart Foundation and the Netherlands Foundation of Scientific Research (projects 901-04-092 and 903-39-117). M. Hofker is an Established Investigator of the Netherlands Heart Foundation.

\section{References}

1. Shulman, R.S., P.N. Herbert, K. Wehrly, and D.S. Fredrickson. 1975. The complete amino acid sequence of CI (apo Lp = Ser), an apolipoprotein from human very low density lipoprotein. J. Biol. Chem. 250:182-190.

2. Havel, R.J., C.J. Fielding, T. Olivecrona, V.G. Shore, P.E. Fielding, and T. Egelrud. 1973. Cofactor activity of protein components of human very low density lipoproteins in the hydrolysis of triglycerides by lipoprotein lipase from different sources. Biochemistry. 12:1828-1833.

3. Brown, V., and M.L. Baginsky. 1972. Inhibition of lipoprotein lipase by an apolipoprotein of human very low density lipoprotein. Biochim. Biophys. Acta. 46:375-382.

4. Windler, E., and R.J. Havel. 1985. Inhibitory effects of C apolipoproteins from rats and humans on the uptake of triglyceride-rich lipoproteins and their remnants by the perfused rat liver. J. Lipid Res. 26:556-565.

5. Quarfordt, S.H., G. Michalopoulos, and B. Schirmer. 1982. The effect of human $\mathrm{C}$ apolipoproteins on the in vitro hepatic metabolism of triglyceride emulsions in the rat. J. Biol. Chem. 257:14642-14647.

6. Sehayek, E., and S. Eisenberg. 1991. Mechanisms of inhibition by apolipoprotein $\mathrm{C}$ of apolipoprotein $\mathrm{E}$-dependent cellular metabolism of human triglyceride-rich lipoproteins through the low density lipoprotein receptor. J. Biol. Chem. 266:18259-18267.

7. Weisgraber, K.H., R.W. Mahley, R.C. Kowal, J. Herz, J.L. Goldstein, and M.S. Brown. 1990. Apolipoprotein C-I modulates the interaction of apolipoprotein $\mathrm{E}$ with $\beta$-migrating very low density lipoproteins ( $\beta$-VLDL) and inhibits binding of $\beta$-VLDL to low density lipoprotein receptor-related protein. J. Biol. Chem. 265:22453-22459.

8. Swaney, J.B., and K.H. Weisgraber. 1994. Effect of apolipoprotein C-1 peptides on the apolipoprotein $\mathrm{E}$ content and receptor-binding properties of beta-migrating very low density lipoproteins. J. Lipid Res. 35:134-142.

9. Simonet, W.S., N. Bucay, R.E. Pitas, S.J. Lauer, and J.M. Taylor. 1991. Multiple tissue-specific elements control the apolipoprotein $\mathrm{E} / \mathrm{C} 1$ gene locus in transgenic mice. J. Biol. Chem. 266:8651-8654.

10. van Ree, J.H., M.H. Hofker, W.J.A.A. van den Broek, J.M.A. van Deursen, H. van der Boom, R.R. Frants, B. Wieringa, and L.M. Havekes. 1995. Increased response to cholesterol feeding in apolipoprotein $\mathrm{C}-1$ deficient mice. Biochem. J. 305:905-911.

11. Hogan, B., F. Costantini, and E. Lacey. 1986. Manipulating the Mouse Embryo: a Laboratory Manual, Cold Spring Harbor Laboratory Press, Cold Spring Harbor, New York. pp 253-290.

12. van den Maagdenberg, A.M.J.M., M.H. Hofker, P.J.A. Krimpenfort, I.H. de Bruijn, B.J.M. van Vlijmen, H. van der Boom, L.M. Havekes, and R.R. Frants. 1993. Transgenic mice carrying the apolipoprotein E3-Leiden gene exhibit hyperlipoproteinemia. J. Biol. Chem. 268:10540-10545.

13. Zannis, V.I., J. McPherson, G. Goldberger, S.U. Karathanasis, and J.L. Breslow. 1984. Synthesis, intracellular processing, and signal peptide of human apolipoprotein E. J. Biol. Chem. 259:5495-5499.

14. Hoffer, M.J.V., M.H. van Eck, L.M. Havekes, M.H. Hofker, and R.R. Frants. 1993. The mouse apolipoprotein C1 gene: structure and expression. Genomics. 18:37-42.

15. Horiuchi, K., S. Tajima, M. Menu, and A. Yamamoto. 1989. Structure and expression of mouse apolipoprotein E gene. J. Biochem. 106:98-103.

16. Fort, P., L. Marty, M. Piechaczyk, S.E. Sabrouty, C. Dani, P. Jeanteur, and J.M. Blanchard. 1985. Various rat adult tissues express only one major mRNA species from the glyceraldehyde-3-phosphate-dehydrogenase multigenic family. Nucleic Acids Res. 13:1431-1442.

17. Nishina, P.M., J. Verstuyft, and B. Paigen. 1990. Synthetic low and high fat diets for the study of atherosclerosis in the mouse. J. Lipid Res. 31:859-869.

18. van Vlijmen, B.J.M., A.M.J.M. van den Maagdenberg, M.J.J. Gijbels, H. van der Boom, H. HogenEsch, R.R. Frants, M.H. Hofker, and L.M. Havekes.
1994. Diet-induced hyperlipoproteinemia and atherosclerosis in apolipoprotein E3-Leiden transgenic mice. J. Clin. Invest. 93:1403-1410.

19. van Ree, J.H., J.A.A. van den Broek, V.E.H. Dahlmans, P.H.E. Groot, M. Vidgeon-Hart, R.R. Frants, B. Wieringa, L.M. Havekes, and M.H. Hofker. 1994. Diet-induced hypercholesterolemia and atherosclerosis in heterozygous apolipoprotein E-deficient mice. Atherosclerosis. 111:25-37.

20. Lowry, O.H., N.J. Rosebrough, A.L. Farr, and R.J. Randall. 1951. Protein measurement with the folin phenol reagent. J. Biol. Chem. 193:265-275.

21. Bligh, E.G., and W.J. Dyer. 1959. A rapid method of total lipid extraction and purification. Can. J. Biochem. Physiol. 37:911-917.

22. Bernstein, S.E. 1979. Physiological characteristics. In Biology of the Laboratory Mouse. 2nd ed. E.L. Green, editor. Dover publications. Inc., New York. 337-350.

23. Moir, A.M.B., and V.A. Zammit. 1992. Selective labeling of hepatic fatty acids in vivo. Biochem. J. 283:145-149.

24. Aalto-Setala, K., E.A. Fisher, X. Chen, T. Chajek-Shaul, T. Hayek, R. Zechner, A. Walsh, R. Ramakrishnan, H.N. Ginsberg, and J.L. Breslow. 1992. Mechanism of hypertriglyceridemia in human apolipoprotein (Apo) CIII transgenic mice. J. Clin. Invest. 90:1889-1900.

25. Willnow, T.E., Z. Sheng, S. Ishibashi, and J. Herz. 1994. Inhibition of hepatic chylomicron remnant uptake by gene transfer of a receptor antagonist. Science. (Wash. DC). 264:1471-1474.

26. Herz, J., and R.D. Gerard. 1993. Adenovirus-mediated transfer of low density lipoprotein receptor gene acutely accelerates cholesterol clearance in normal mice. Proc. Natl. Acad. Sci. USA. 90:2812-2816.

27. Fallaux, F.J., O. Kranenburg, S.J. Cramer, A. Houweling, H. van Ormondt, R.C. Houben, and A.J. van der Eb. 1996. Characterization of 911: a new helper cell line for the titration and propagation of early region 1-deleted adenoviral vectors. Hum. Gene Ther. 7:215-222.

28. van Dijk, M.C.M., W. Boers, C. Linthorst, and T.J.C. van Berkel. 1992. Role of the scavenger receptor in the uptake of methylamine-activated $\alpha_{2}$-macroglobulin by rat liver. Biochem. J. 287:447-455.

29. van Vlijmen, B.J.M., H.B. van 't Hof, M.J.T.M. Mol, H. van der Boom, A. van der Zee, R.R. Frants, M.H. Hofker, and L.M. Havekes. 1996. Modulation of very low density lipoprotein production and clearance contributes to age- and gender-dependent hyperlipoproteinemia in apolipoprotein E3-Leiden transgenic mice. J. Clin. Invest. 97:1184-1192.

30. Jong, M.C., V.E.H. Dahlmans, P.J.J. van Gorp, M.L. Breuer, M.J.T.M. Mol, A. van der Zee, R.R. Frants, M.H. Hofker, and L.M. Havekes. 1996. Both lipolysis and hepatic uptake of very low density lipoproteins are impaired in transgenic mice co-expressing human apolipoprotein $\mathrm{E}^{*} 3$ Leiden and human apolipoprotein C1. Arterioscler. Thromb. Vasc. Biol. 16:934-940.

31. Shachter, N.S., T. Hayek, T. Leff, J.D. Smith, D.W. Rosenberg, A. Walsh, R. Ramakrishnan, I.J. Goldberg, H.N. Ginsberg, and J.L. Breslow. 1994. Overexpression of apolipoprotein CII causes hypertriglyceridemia in transgenic mice. J. Clin. Invest. 93:1683-1690.

32. de Silva, H.V., S.J. Lauer, J. Wang, W.S. Simonet, K.H. Weisgraber, R.W. Mahley, and J.M. Taylor. 1994. Overexpression of human apolipoprotein C-III in transgenic mice results in an accumulation of apolipoprotein B48 remnants that is corrected by excess apolipoprotein E. J. Biol. Chem. 269:23242335 .

33. Choi, S.Y., L.G. Fong, M.J. Kirven, and A.D. Cooper. 1991. Use of an anti-low density lipoprotein receptor antibody to quantify the role of the LDL receptor in the removal of chylomicron remnants in the mouse in vivo. J. Clin. Invest. 88:1173-1181.

34. Choi, S.Y., and A.D. Cooper. 1993. A comparison of the roles of the low density lipoprotein (LDL) receptor and the LDL receptor-related protein $/ \alpha_{2}-$ macroglobulin receptor in chylomicron remnant removal in the mouse in vivo. J. Biol. Chem. 268:15804-15811.

35. Ishibashi, S., M.S. Brown, J.L. Goldstein, R.D. Gerard, R.E. Hammer, and J. Herz. 1993. Hypercholesterolemia in low density lipoprotein receptor knockout mice and its reversal by adenovirus-mediated gene delivery. J. Clin. Invest. 92:883-893.

36. Herz, J., and T.E. Wilnow. 1995. Lipoprotein and receptor interactions in vivo. Curr. Opin. Lipidol. 6:97-103.

37. Havel, R.J. 1995. Chylomicron remnants: hepatic receptors and metabolism. Curr. Opin. Lipidol. 6:312-316.

38. Kowal, R.C., J. Herz, J.L. Goldstein, V. Esser, and M.S. Brown. 1989. Low density lipoprotein receptor-related protein mediates uptake of cholesteryl esters derived from apolipoprotein E-enriched lipoproteins. Proc. Natl. Acad. Sci. USA. 86:5810-5814.

39. Willnow, T.E., S.A. Armstrong, R.E. Hammer, and J. Herz. 1995. Functional expression of low density lipoprotein receptor-related protein is controlled by receptor-associated protein in vivo. Proc. Natl. Acad. Sci. USA. 92: 4537-4541.

40. Shimano, H., Y. Namba, J. Ohsuga, M. Kawamura, K. Yamamoto, M. Shimada, T. Gotoda, K. Harada, Y. Yazaki, and N. Yamamda. 1994. Secretionrecapture process of apolipoprotein $\mathrm{E}$ in hepatic uptake of chylomicron remnants in transgenic mice. J. Clin. Invest. 93:2215-2223. 